\title{
On College Students' Listening Anxiety and Listening Strategy
}

\author{
Zhen Zhou \\ Foreign Language School, Nanchang Normal University, Nanchang, Jiangxi, China
}

\begin{abstract}
Research on college students' listening anxiety and listening strategy has become a hot issue and attracts much concern of scholars and experts in the second language acquisition. Some researches prove that listening anxiety is universal and pervasive in the language learning process and listening strategy plays a crucial role in lowering or reducing college students' listening anxiety and improving their listening ability. In order to study college students' listening anxiety, listening strategy and the correlation between college students' listening anxiety and listening strategy, an empirical study is carried out on the $2020^{\text {th }}$ English majors. This study combines quantitative method and qualitative method and adopts "Questionnaire about English listening strategy" and "Questionnaire about English listening anxiety". The study reveals that: firstly, among the listening strategy, meta-cognitive strategy is the most frequent strategy that college students use; cognitive strategy is more frequent than social or affective strategy used by college students; social or affective strategy is the least frequent strategy that college students use. Secondly, although college students suffer from universal listening anxiety, the level of listening anxiety is low. Thirdly, the correlation between college students' listening anxiety and listening strategy is not significant. It also means that listening anxiety is not related to social or affective strategy, related to meta-cognitive strategy. This study aims to help Chinese college educators and students to realize the effect of listening anxiety and the appropriate use of listening strategy.
\end{abstract}

Index Terms - listening anxiety, anxiety level, listening strategy, correlation, frequency of use

\section{INTRODUCTION}

Listening is a very complicated process, because it takes place timely and never comes back. Listeners must pay attention to the listening process and remember the content they have heard. If listeners do not have sufficient listening competence, they will lose the significant items of information and fail in the process of decoding information (Kim, 2000). Researchers and learners have studied the relationship between anxiety and specific language skills, such as speaking, listening, reading and writing since 1980s. Horowitz (2001) states that, "individual emotional factors, such as self-esteem, motivation, attitude, anxiety, expectation, inhibition and tolerance, are essential to language learning process, especially for learners who have equal intelligence in similar educational environment." Horowitz and Cope (1986) propose that, anxiety, in the language learning process, is one of the most obviously psychological phenomenon and listening is a dominant part that can trigger foreign language learners' anxiety. Therefore, students may have more anxiety in listening process. In order to overcome the listening obstacle caused by anxiety, more and more researchers and learners focus on listening strategies. Different students with different language proficiency usually use different strategies. Owing to the differences of subjects and instruments, there still arrives no agreement among these studies.

After reviewing some studies, it finds that, researchers and educators have achieved great advances in the studies of language anxiety and language strategy, which help researchers to measure language anxiety and language strategy validly and reliably. However, some places need to consider and study further. Firstly, some researchers and learners studied the relationship or correlation between anxiety and language strategies in a broad way. They just investigate the relationship between general foreign language anxiety and the use of general strategies. Therefore, it is important and necessary for researchers to probe the relationship between anxiety and learning strategies linking to specific language learning skills, particularly the relationship between listening anxiety and listening strategies. Secondly, in some studies, the selected subjects are not typical, which may produce error and affect the survey's effect. In this study, the research subjects are college students and the number of the research subjects is eighty-four. Both boys and girls are included. Thirdly, in these empirical studies, the relationship between English listening anxiety and listening strategies is not analyzed generally and integrally. Therefore, some improvements and modifications need to be done in this thesis. The things that researchers and learners need to do are, finding out the reasons and conditions of college students' listening anxiety, the general relationship between English listening anxieties and listening strategy.

\section{RESEARCH METHODOLOGY}

\section{A. Research Subjects}

In this study, research subjects are from a normal university, in Jiangxi province. Two classes, adding up to 84 students, are selected as research subjects. All the research subjects are chosen at random, which can contribute to the 
objectivity and the authenticity of this research. They are consisted of 78 girls and 6 boys in the study. These subjects are English majors, from the department of foreign languages. Therefore, the number of female is much larger than the number of male.

\section{B. Research Instrument}

In the present study, all the research data is collected through the use of questionnaires. There are two important questionnaires, which is used to investigate the relationship and correlation between college students' listening learning strategy and listening anxiety. The two questionnaires are respectively "Questionnaire about English listening learning strategy" and "Questionnaire about English listening anxiety". In the "Questionnaire about English listening learning strategy", there are 38 items. And three necessary factors are involved in this questionnaire. The factors are cognitive strategy, meta-cognitive strategy and social or affective strategy. In the "Questionnaire about English listening anxiety", there are 18 items, which are used to describe college students' English listening anxiety.

\section{Data Collecting}

The validness of the recycling questionnaires has been analyzed after finishing the questionnaires. 84 questionnaires are valid. All the data are collected in the computer and processed by SPSS21 to get the descriptive statistics about English listening anxiety, English listening strategy and the correlation or relationship between listening anxiety and English listening strategy.

\section{FINDINGS}

Research data from the two questionnaires about English listening strategy and listening anxiety are processed by SPSS22.0. Then, it gets a clearer data about listening strategy and listening anxiety.

\section{A. General Introductions}

In order to investigate the conditions about college students' English listening strategy and listening anxiety, research data from the two questionnaires about English listening strategy and listening anxiety are processed by SPSS21. It gets a clearer data.

TABLE 1.

DESCRIPTIVE STATISTICS ABOUT ENGLISH LiSTENING STRATEGY AND LISTENING ANXIETY

\begin{tabular}{lllll}
\hline & Min & Max & Mean & SD \\
\hline Meta-cognitive strategy & 1.20 & 5.00 & 3.1071 & 0.80746 \\
& & & & \\
Cognitive strategy & 1.00 & 4.17 & 2.5893 & 0.67289 \\
Social or affective strategy & 1.96 & 5.00 & 2.9276 & 0.49192 \\
Listening anxiety & 1.44 & 4.44 & 2.7771 & 0.59577 \\
\hline
\end{tabular}

Through analyzing the mean value in questionnaire about English listening strategy, it is obvious that, among the listening strategy, meta-cognitive strategy (Mean=3.1071) is the most frequent strategy used by college students; then, the use of cognitive strategy (Mean=2.9276) is more frequent than the use of social or affective strategy; social or affective strategy (Mean=2.5893) is the least frequent strategy used by college students. Through analyzing the mean value from the questionnaire about English listening anxiety, it indicates that listening anxiety $(\mathrm{M}=2.7771)$ is universal, but college students are in a low-level anxious state. Through analyzing the standard deviation value, the differences of use in meta-cognitive strategies $(\mathrm{SD}=0.80746)$ are the biggest one. The use of social or affective strategy $(\mathrm{SD}=0.67289)$ is more different than the use of cognitive strategy ( $\mathrm{SD}=0.49192)$. The standard deviation value of anxiety is 0.59577 . It indicates that, as far as college students are concerned, listening anxiety is a universal phenomenon.

In a word, all English listening strategies have various types of use and college students use them with different frequencies. Although college students suffer from listening anxiety in the process of English listening learning, the levels of their listening anxiety are low. It is a strange phenomenon, which should be analyzed more deeply.

\section{B. Research Results about English Listening Strategies}

Listening strategy is a behavior and thought that listeners engage in during listening learning process. Listening strategy is used to influence the listening encoding and decoding process. In other word, listening strategy is a behavior that listeners use to make listening more successful, enjoyable and convenient. The listening strategy consists of cognitive strategy, meta-cognitive strategy and social or affective strategy.

\section{Ten Most Frequently Used English Listening Strategies}

The questionnaires adopt Likert's five point scoring system. "If the mean value is above 3.5, it means that this English listening strategy is used more frequently. If the mean value is between 2.5 and 3.5, it indicates that the English listening strategy is used sometimes. If the mean value is below 2.5, it shows that the English listening strategy is used rarely." (Likert, 1990) 
TABLE 2

\begin{tabular}{|c|c|c|c|c|c|}
\hline Items & Min & $\operatorname{Max}$ & Mean & SD & Rank \\
\hline S2 & 2.00 & 5.00 & 3.8095 & 0.93752 & 1 \\
\hline S36 & 1.00 & 5.00 & 3.6667 & 1.07919 & 2 \\
\hline S13 & 1.00 & 5.00 & 3.5476 & 1.10208 & 3 \\
\hline S14 & 1.00 & 5.00 & 3.5119 & 1.01191 & 4 \\
\hline S8 & 1.00 & 5.00 & 3.3929 & 1.13028 & 5 \\
\hline S9 & 1.00 & 5.00 & 3.3571 & 1.11553 & 6 \\
\hline S34 & 1.00 & 5.00 & 3.2262 & 1.32038 & 7 \\
\hline S31 & 1.00 & 5.00 & 3.1548 & 1.13535 & 8 \\
\hline S1 & 1.00 & 5.00 & 3.1071 & 1.02989 & 9 \\
\hline S3 & 1.00 & 5.00 & 3.1071 & 1.18238 & 10 \\
\hline
\end{tabular}

From this descriptive statistical result about listening learning strategies, study deeper on listening strategies which college students use more frequently. The results indicate that S2, S36, S13, S14, S8, S9, S34, S31, S1 and S3 are ten types of English listening strategies that college students use more frequently. They are ranked in order. The mean values of S2, S36, S13 and S14 are above 3.5, which means that these strategies are effective and helpful in English listening learning process. The mean values of S8, S9, S34, S31, S1, and S3 between 2.5 and 3.5, which indicates that college students use these English listening learning strategies sometimes. In addition, S36 and S14 belong to meta-cognitive strategy. S36 is that, in listening learning process, college students often remind themselves of concentrating on listening practice. S14 means that students spend much time on some places, which are related to listening questions. S2, S13, S8, S9, S1 and S3 belong to cognitive strategy. S2 is when college students are not familiar with the words they encounter, they will keep listening. S13 says that after scanning the listening questions, students will make some predictions and speculations of listening content. S34 and S31 belong to social or affective strategy. S34 is that in listening exam, students meet listening problems, they will give themselves some positive implications. They will tell themselves "do not worry, everyone has difficulties in the listening test". S31 indicates that doing listening practice before listening test can lower or reduce college students' listening anxiety.

\section{Ten Least Frequently Used English Listening Strategies}

The mean value is used to reflect the listening learning strategy's frequency of use. And the value of standard deviation is used to reflect the listening learning strategy's dispersion degree of the data. The values of standard deviation are larger, and the listening strategy's differences are larger.

TABLE 3

DESCRIPTIVE STATISTICS ABOUT TEN LEAST FREQUENTLY USED ENGLiSH LiSTENING STRATEGIES

\begin{tabular}{llllll}
\hline Items & Min & Max & Mean & SD & Rank \\
\hline S38 & 1.00 & 4.00 & 1.6071 & 0.89197 & 1 \\
S37 & 1.00 & 5.00 & 1.9286 & 0.90228 & 2 \\
S27 & 1.00 & 5.00 & 1.9643 & 0.94991 & 3 \\
S6 & 1.00 & 5.00 & 2.2024 & 1.05030 & 4 \\
S33 & 1.00 & 5.00 & 2.3452 & 1.15638 & 5 \\
S4 & 1.00 & 5.00 & 2.4286 & 1.10077 & 6 \\
S16 & 1.00 & 5.00 & 2.5595 & 0.99821 & 7 \\
S26 & 1.00 & 5.00 & 2.5595 & 0.99821 & 8 \\
S11 & 1.00 & 5.00 & 2.5952 & 1.12066 & 9 \\
S22 & 1.00 & 5.00 & 2.6190 & 1.16065 & 10 \\
\hline
\end{tabular}

From this descriptive statistical result about English listening strategies, study goes deeper on listening strategies which college students use less frequently. The results indicate that S38, S37, S27, S6, S33, S4, S16, S26, S11, S22 are ten types of English learning listening strategies which college students use less frequently. They are arranged in order. The mean values of S16, S26, S11 and S22 are between 2.5 and 3.5, which indicate that these English listening learning strategies are used sometimes. The mean values of S38, S37, S27, S6, S33 and S4 are below 2.5, which show that these English listening learning strategies are used rarely.

S38 and S16 belong to meta-cognitive strategy. S38, students often persist a writing learning diary habit, recording the emotions as they are listening and finding the difficulties they need to deal with. S16, students often have definite listening practice goal and plan when they do listening exercise.

S37, S27 and S33 belong to social or affective strategy. S37, students often discuss about their listening anxiety with classmates or their teachers. And students ask for their help to reduce listening anxiety. S27, students often communicate with others, such as teachers or classmates, in order to explore effective ways to improve listening comprehension ability. S3, students often talk about some relaxing topics to reduce or release their listening anxiety before listening test.

S6, S4, S26, S11 and S22 belong to cognitive strategy. S6, students often take different methods, which correspond to different types of topics. S4, students often concentrate their attention to distinct different meanings of a sentence as a sentence is spoken with different tones. S26, students often take notice of the relationship among listening, speaking, writing, and reading skills. Doing comprehensive exercise can contribute to college students' listening ability. S11, in 
listening process, while they are listening, students take notes on key words, for example, character, time, place, the simple process of a thing taking place. S22, students often tend to repeat the conversations that they have listened by using their own words that they have listened.

\section{E. Research Results about Listening Anxiety}

When the humanistic psychology came into being, educators and psychologists have begun to research anxiety. And language researchers think that, "anxiety, as one of the affective factors, has a great importance on language learning. (Horwitz, 2000)" It also has a direct influence on people's behavior. Horwitz (2000) proposed that individuals' emotional variables, such as self-esteem, motivation, inhibition, and anxiety are necessary for language learners, especially for people who having equal intelligence and growing in similar educational environments (Horwitz, 2000). Anxiety is a significant factor among numerous emotional variables and has a important state. It should obtain enough attention and deep research.

As it is defined in Andrew D.C Cohen's book (1998), anxiety is a kind of aberrant emotion, which is also a kind of mental abnormality. In the opinion of Elkhafaifi (2005), "generally, it refers to an actual fear-like response or to a tendency to respond with fear to any current or anticipated situation that is perceived as a potential threat to self-esteem. It differs from ordinary fear in that the threat is directed against self-esteem rather than against physical well-being, and may be anticipated or current in nature." According to O'Malley J.M and Chamot, A.U (1982), "anxiety refers to a cognitive-affective response characterized by physiological arousal (indicative of sympathetic nervous system activation) and apprehension regarding potentially negative outcomes that the individual perceives as impeding." The definition of anxiety is put forward by Spielberger (1998). Anxiety is an unpleasant emotional state or condition and it is characterized by the subjective feeling of tense, apprehension, nervousness and worry, which activates or arise the automatic nervous system.

\section{F. Six Types of Conditions Causing College Students'High-Level Listening Anxiety}

The mean value is used to reflect the level of listening anxiety. The value of standard deviation is used to reflect the listening anxiety's dispersion degree of data. The value of mean is larger, and the listening anxiety is in a higher level. The values of standard deviation are larger, and the differences of listening anxiety are larger.

TABLE 4

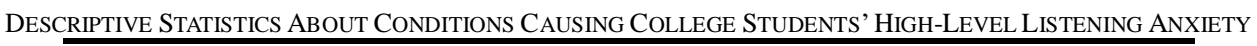

\begin{tabular}{llllll}
\hline Items & Min & Max & Mean & SD & Rank \\
\hline A8 & 1.00 & 5.00 & 4.0119 & 1.08099 & 1 \\
A1 & 1.00 & 5.00 & 3.6190 & 0.98059 & 2 \\
A9 & 1.00 & 5.00 & 3.4643 & 1.12417 & 3 \\
A10 & 1.00 & 5.00 & 3.0833 & 1.12162 & 4 \\
A12 & 1.00 & 5.00 & 2.9643 & 1.02318 & 5 \\
A6 & 1.00 & 5.00 & 2.9643 & 1.13484 & 6 \\
\hline
\end{tabular}

From this descriptive statistical result about listening anxiety, study goes deeper on listening conditions which rise college students' high-level listening anxiety. The results indicate that A8, A1, A9, A10, A12 and A6 are six types of English listening conditions rising college students' high-level listening anxiety, which are arranged in order. The mean values of $\mathrm{A} 8$ and $\mathrm{A} 1$ are above 3.5, which indicates that college students often are anxious and nervous. The mean values of A9, A10, A12 and A6 are between 2.5 and 3.5, which indicates that college students are anxious and nervous sometimes. A8, in English listening class, students often feel not easy and anxious, because they are not satisfied with their listening ability. They think the listening test is too difficult for them to make full comprehension about English listening materials. A1, as they are listening to the tape, students rarely feel confident. At this time, they are in high-level listening anxiety. A9, when the listening tape's speed is too fast, students are often nervous and highly anxious. A10, students often think that other students' listening comprehension is better than themselves. This psychological phenomenon can lead to low self-confidence and self-efficacy. A12, when encountering a sentence with complicated sentence structure in listening process, students often feel upset. It is harmful for college students to deal with listening difficulties. A6, students do not like all kinds of English materials, such as English listening tape, English songs, English radios and English news on TV. Without interest, all things become more difficult that it is in reality. Therefore, the level of listening anxiety is higher than it should be.

\section{G. Six Types of Listening Conditions Causing College Students'Low-Level Listening Anxiety}

From this descriptive statistical result about listening anxiety, study goes deeper on college students' less low-level listening anxiety. 
TABLE 5

\begin{tabular}{|c|c|c|c|c|c|}
\hline Items & Min & Max & Mean & SD & Rank \\
\hline A11 & 1.00 & 5.00 & 2.0714 & 0.99136 & 1 \\
\hline A5 & 1.00 & 5.00 & 2.0833 & 0.98431 & 2 \\
\hline A3 & 1.00 & 5.00 & 2.2262 & 0.94870 & 3 \\
\hline A14 & 1.00 & 5.00 & 2.2381 & 1.08238 & 4 \\
\hline A13 & 1.00 & 5.00 & 2.2976 & 1.15935 & 5 \\
\hline A7 & 1.00 & 5.00 & 2.4167 & 1.32818 & 6 \\
\hline
\end{tabular}

The results indicate that the mean values of A11, A5, A3, A14, A13 and A7 are below 2.5. They are six types of English listening conditions rising students' low-level listening anxiety, which are arranged in order. A11, in listening learning class, students are not positive and active in answering questions. They are afraid of negative respond from other classmates or teachers. A5, when students are interested in English listening class, they will feel less anxious. A3, students feel anxious and nervous as soon as they know they are going to listen to an English essay. A14, students are often in a low level of anxiety, as they hear of some topics about western culture or western thoughts or views. Because they are not familiar to college students, A13, students are afraid of the bad results resulting from terrible behavior in listening class. A7, students often believe that listening is the most complicated parts among English learning process.

\section{H. Research Results about the Relationship between College Students Listening Anxiety and Listening Strategy}

"Pearson correlation coefficient is a method to measure the correlation between two variables. It is a value between -1 and 1 . If the value is 1 , it means that the two variables are positively related. If the value is -1 , it means that the two variables are negatively related to each other. If the value is 0 , it means that the two variables are independent.(Pearson, 1980s)". If the absolute value of ' $r$ ' is above 0.5 , it indicates that two variables are in a high correlation. If the absolute value of ' $r$ ' is between 0.3 and 0.5 , it indicates that two variables are in a low correlation. If the absolute value of ' $r$ ' is below 0.3 , it indicates that two variables are in no correlation.

TABLE 6

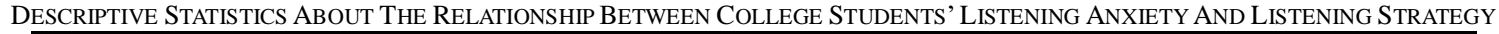

\begin{tabular}{|c|c|c|c|c|c|c|}
\hline & & Meta-cognitive strategy & $\begin{array}{l}\text { Cognitive } \\
\text { strategy }\end{array}$ & $\begin{array}{l}\text { Social } \\
\text { affective } \\
\text { strategy }\end{array}$ & or & $\begin{array}{l}\text { Listening } \\
\text { anxiety }\end{array}$ \\
\hline \multirow{3}{*}{$\begin{array}{l}\text { Listening } \\
\text { anxiety }\end{array}$} & Pearson correlation & -0.167 & -0.167 & $-0.277^{*}$ & & 1 \\
\hline & $\begin{array}{l}\text { Significance } \\
\text { (double) }\end{array}$ & 0.128 & 0.128 & 0.011 & & \\
\hline & $\mathrm{N}$ & 84 & 84 & 84 & & 84 \\
\hline
\end{tabular}

From this descriptive statistical result about the relationship between listening anxiety and listening learning strategy, study goes deeper on the relationship between listening anxiety and listening learning strategy. The Pearson correlation value between listening anxiety and meta-cognitive strategy is -0.167 . It reveals that listening anxiety is not related to meta-cognitive strategy. The Pearson correlation value between listening anxiety and cognitive strategy is -0.167 . It shows that listening anxiety is not related to cognitive strategy. The Pearson correlation value between listening anxiety and social or affective strategy is -0.227 * It indicates that listening anxiety is related negatively to social or affective strategy. Above all, the absolute value of ' $r$ ' is below 0.3 , that is, college students' listening anxiety has no correlation to English listening strategy.

\section{CONCLUSION}

In this empirical study, the correlation between listening anxiety and listening strategy has been found. The study reveals that the listening strategies have no influence on reducing students' listening anxiety. It is probable that college students with lower listening anxiety may use listening strategies more frequently. In the present study, it reports that over half college students suffer from listening anxiety. The differences between Chinese and English may account for the listening anxiety that college students are experiencing.

The present study attempts to explore the influences of listening anxiety, the effects of listening strategies, and the correlation between listening anxiety and English listening learning strategy in listening learning practice. The findings of the present aim to provide some implications for the English learning practice, especially for the listening learning practice.

The implications for educational practice are following:

(1) Chinese college students suffer from universal listening anxiety. Teachers should be conscious of this phenomenon and help students to acknowledge their listening anxiety. It is a problem that we need to solve rather than flee. There are many ways that we can take to reduce listening anxiety. "Sharing of common feelings of nervousness or frustration with the group may elicit creative ways to solve the problem for the whole class" (Elkhafaifi, 2005). Students should keep in mind that listening anxiety can be reduced through time, experience, hard working, and 
effective listening strategies.

(2) The use of methods and techniques cannot make listening learning more effectively and quickly. Maybe the methods or techniques are not selected appropriately to deal with listening problems. In the listening learning process, teachers' jobs are not just playing the tape. The more important thing is teaching college students appropriate, useful and effective listening strategies to reduce listening anxiety. Meanwhile, listeners should do abundant exercises to improve their listening skills. With the help of the listening strategies, college students can become more self-confident to deal with their listening anxiety problems. Furthermore, these strategies encourage college students to be an individual actively and positively in the listening learning process. Listening learning is a process which needs cooperation. Therefore, it is suggested that both teachers and students should be the participants in the listening learning activities. And listening strategies should be combined with listening tasks.

(3) The responses of students in the listening learning activities have a great influence on students' performance. Therefore, a professional teacher must be skilled in using positive expressions and evaluations however the students perform in the listening exercises. In a word, creating an easy and low-anxiety environment is fundamental for learners to act successfully. In the study, it reveals that if college students get positive feedback, their self-efficacy and self-confidence can get improvements, in which college students' listening anxiety is in a low level.

(4) In Chinese class, college students are required to present themselves better and better. In such circumstance, college students are obliged to shoulder great stress and burden. Teachers should focus the progress that college students have made, rather than that they have not made. Therefore, in order to improve learners' listening competences, teachers need to create a secure, low-anxiety atmosphere. In this atmosphere, learners are encouraged to participate in listening learning activities and the process is more important than the results.

\section{ACKNOWLEDGEMENTS}

This study was financially supported by "11531" Construction Project of Nanchang Normal University of China (English Language and Literature Discipline Construction, Project of Humanities and Social Sciences of Nanchang Normal University; "A Survey on the Writing Anxiety of Undergraduate Thesis of English Teachers College" (19RWZD01), and Education Reform Project of Nanchang Normal University;"A Study on the Teaching Model of "Divided Classroom" in College English from the Perspective of Erosion Theory" (18JGKT-01)).

\section{REFERENCES}

[1] Benjamin, D. (1981). Test anxiety: deficit in information processing. Journal of Educational Psychology, 73, 816-824.

[2] Campell, C. M. Ortiz. (1991). Helping students overcome foreign language anxiety: A foreign language anxiety workshop. In Horwitz Elaine. K. and Dolly, J. Young, Eds. Language Anxiety: From Theory and Research to Classroom Implications Englewood Cliffs, NJ: Prentice Hall.

[3] Chen Xiu. (2014). Research on English listening comprehension and anxiety and its teaching implications. Foreign Language Audio Visual Teaching, 2, 21-25.

[4] Chen Yanjun. (2015). Foreign language listening anxiety of Chinese non-English majors, Journal of Hunan Normal University, 6, 13-17.

[5] Elkhafaifi, H. (2005). Listening comprehension and anxiety in the Arabic language classroom. Modern Language Journal, 89, 206-220.

[6] Hao Mei, Hao ruoping. (2016). Correlation between English achievement and achievement motivation, state anxiety. Foreign Language and Foreign Language Teaching. 4, 32-35.

[7] Huang Lulu. (2018). A case study on English Listening Learning Strategies in Higher Vocational Colleges. Journal of Harbin Vocational and Technical College, 3, 56-58.

[8] Kim, J. H. (2000). Foreign language listening anxiety: A Study of Korean Students Learning English. Doctoral dissertation, the University of Texas, Austin.

[9] Shi Jiali. (2017). Correlation between English listening style and listening anxiety of senior high school students. Master's thesis of Yangzhou University.

[10] Wang Li. (2018). Junior middle school English listening teaching strategies. Western Quality Education, 9, 13-18.

[11] Wang Lifei. (2003). An Empirical Study on English learning strategies. Journal of Shaanxi Normal University, 4, 45-50.

[12] Ward, P and Downing. (2000). Learning strategies, learning anxiety and knowledge acquisition. British Journal of Psychology, 6, 31-38.

[13] Watson, D. (2002). Measurement of social evaluative anxiety. Journal of consulting and clinical psychology, 1, 17-24.

[14] Xu Haibo. (2015). Research on listening anxiety and listening learning strategies of non English majors. Journal of Chongqing University, 1, 47-51.

[15] Xu Yinxue. (2016). A study on Freshmen's English listening anxiety and listening strategies. Journal of Chongqing University of Arts and Sciences, 3, 38-43.

[16] Yang Yunwen, Guo Jinghua, Ma Yueqiu. (2018). Process based meta-cognitive strategy teaching in English listening class. Vocational and Technical Education, 5, 24-30. 
Zhen Zhou was born in Ezhou, Hubei province, China in 1981. She received her master degree in English teaching method from Hubei University, China in 2008.

She is currently an associate professor in the School of Foreign Languages, Nanchang Normal University, Nanchang, China. Her research interests include English teaching psychology and English teaching method. 